7. Reprod. Fert. (1968) 17, 247-251

\title{
THE OESTROUS CYCLE IN THE MONGOLIAN GERBIL, MERIONES UNGUICULATUS
}

\author{
M. ASHTON BARFIELD* AND ELIZABETH A. BEEMAN \\ Department of Biological Sciences, Mount Holyoke College, South Hadley, Massachusetts
}

(Received 23rd October 1967, revised 21st November 1967)

\begin{abstract}
Summary. Daily pairing of normal adult female gerbils with indicator males revealed an oestrous cycle of 4 to 6 days. Under the conditions of the experiment, oestrous behaviour usually began between 12.00 and 17.00 hours and lasted less than $24 \mathrm{hr}$ (probably 12 to $15 \mathrm{hr}$ ). The appearance, in vaginal smears, of small cornified elements termed 'transitional cells' was partially useful in predicting the approach of receptivity. However, the vaginal smear was reliable only as a general indicator of approaching heat, and gave no temporal information.
\end{abstract}

\section{INTRODUCTION}

The mating behaviour of the Mongolian gerbil resembles that of other rodents in its essentials (Stone, 1922; Louttit, 1927; Reed \& Reed, 1946; Wimer \& Fuller, 1966; Kuehn \& Zucker, 1966). A series of mounts with intromissions culminates in ejaculation, which is followed by a period of grooming and sexual refractoriness. As is frequently the case with a new experimental animal, a number of disparate studies (Gordon \& Cekleniak, 1960; Winkelmann \& Getz, 1962; Walters, Pearl \& Rogers, 1963) has preceded the basic research on the oestrous cycle. Various methods have been used in previous research on rodent cycles: continuous or systematic pairing with the male, elicitation of the copulatory response (lordosis) by fingering, the activity wheel, and examination of vaginal cells obtained either by means of a swab or by lavage. Marston \& Chang (1965) checked established pairs of Mongolian gerbils twice daily for mating behaviour and presence of spermatozoa, and made vaginal smears by lavage. They found it difficult to characterize a regular oestrous cycle. However, in pairings of virgin females, $63 \%$ of the detected matings occurred within 7 days of the initial pairing, and on this basis Marston \& Chang suggested that the gerbil might be polyoestrous, possibly with a short ( 4 to 7 day) cycle. Woodcock (1955) reported a 5-day cycle in Meriones libycus, but gave no supporting evidence.

\section{MATERIALS AND METHODS}

In this study, the most satisfactory method of detecting female receptivity was found to be systematic daily pairing with reliable indicator males. Only two of

* Present address: Department of Biology, Princeton University, Princeton, New Jersey. 
the five adult males available were reliable enough to be used. Twelve normal adult females ( 3 to 20 months) were studied. Although an oestrous female will apparently accept any male, each female was assigned to a specific indicator male to avoid possible female aggression during non-receptive periods. The female was introduced to the indicator male's cage, which was isolated from the rest of the colony. Pairings were 15, then $10 \mathrm{~min}$ long. Since seventy-eight out of eighty matings (in thirty-three receptive periods) began within the first $3 \mathrm{~min}$, $10 \mathrm{~min}$ seemed an adequate period for observation.

The animals were subjected to artificial light from 05.00 to 17.00 hours and pairing sessions were conducted either at 10.00 to 11.00 hours, 15.00 to 17.00 hours and 20.00 to 22.00 hours, or at 12.00 to 14.00 hours and 20.00 to 22.00 hours. Red light was used for observations after 17.00 hours. The observer was in full view of the animals, about $0.5 \mathrm{~m}$ from the cage. Mating was interrupted after several mounts and lordoses had indicated true female receptivity. The number of intromissions permitted averaged three to eight, and never exceeded fifteen. Observations were conducted for a period of 4 to 6 weeks. Beginning $1 \frac{1}{2}$ months before behavioural observations, and continuing throughout the experiment, vaginal smears were made twice daily, at 09.00 to 10.00 hours, and 21.00 to 22.00 hours. Vaginal material was obtained by lavage with $0.25 \mathrm{ml}$ of $0.85 \%$ saline solution containing methylene blue. The material was examined under $\times 100$ magnification, and a typical area was selected for examination at $\times 430$ magnification. The percentage of each cell type in a field was recorded.

\section{RESULTS}

Thirty-three heat periods were detected. Nine of the twelve females came into heat at least once. (Two of the three who failed to display receptivity were 20 months old.) The intervals between periods of heat fell into two groups: 4 to 6 days (av. $4 \cdot 6$ days) and 14 to 18 days (av. 15 days). The only exception was a single 10-day interval (Text-fig. 1). This 10-day interval could be construed as two 5-day intervals with a missed or undetected heat, since the cells in the vaginal smears in the middle of the interval were typical of those found for receptive females (see below).

Since the observations were conducted under two different schedules, data on the onset of heat were obtained for various times of day (Table 1). By far the majority of females were receptive at 15.00 to 17.00 hours on a three/day schedule of observations, and at 12.00 to 14.00 hours on a two/day schedule. Without exception, females were still in behavioural oestrus at the evening session, regardless of the observational schedule or of the time of the onset of heat. In one instance, a female who was first receptive at the morning session would still accept the male the following morning.

Observations were too infrequent for determination of the exact duration of heat. However, all heat periods were known to have lasted at least $5 \mathrm{hr}$, and several were at least 9 to $10 \mathrm{hr}$. One was longer than $23 \mathrm{hr}$. On the other hand, the period of heat was shorter than $24 \mathrm{hr}$ in many instances, and in one case was less than $16 \mathrm{hr}$. Obviously, there is considerable individual variation.

Vaginal smears showed successive dominance of leucocytes, nucleated 
epithelial cells, and cornified epithelial cells. These smears were only partially useful in predicting the onset of receptivity. No attempt was made to determine the duration of the phases of the oestrous cycle or to correlate them with behavioural events, lest excessive handling might have disturbed the natural rhythm.

Several conditions usually preceded receptivity, although the time of their appearance was not correlated with the time of heat. Morning smears preceding receptivity were always devoid of leucocytes. They usually contained nucleated epithelial cells, often in various stages of early cornification. More dependably,

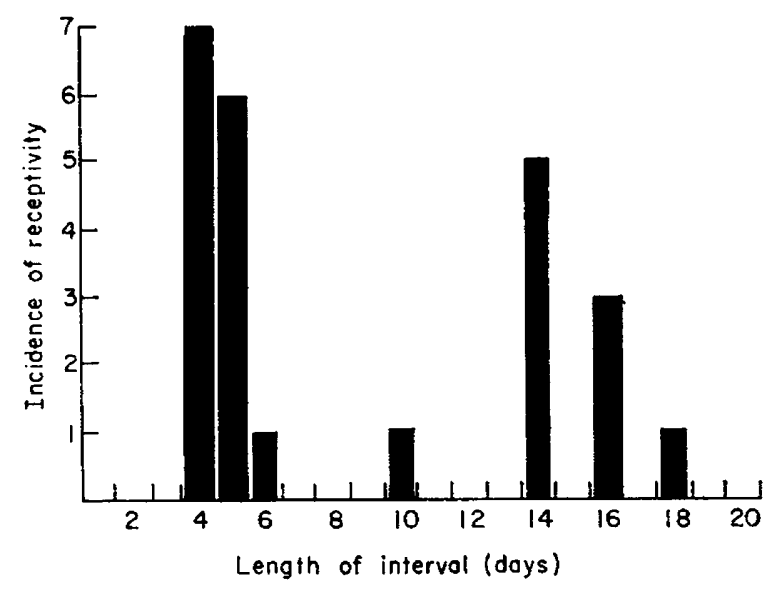

TEXT-FIG. 1. Incidence of various intervals between receptive periods.

TABLE 1

TIME OF DAY AT WHICH RECEPTIVITY WAS FIRST OBSERVED

\begin{tabular}{|c|c|c|c|}
\hline Observation schedule & & Session & $\begin{array}{l}\text { Incidence of } \\
\text { first observed } \\
\text { receptivity }\end{array}$ \\
\hline Observations three/day & $\begin{array}{l}\text { Morning } \\
\text { Mid-afternoon } \\
\text { Evening }\end{array}$ & $\begin{array}{l}10.00 \text { to } 11.00 \text { hours } \\
15.00 \text { to } 17.00 \text { hours } \\
20.00 \text { to } 22.00 \text { hours }\end{array}$ & $\stackrel{4}{14}{ }_{1 *}^{*}(1 / 14 \mathrm{E})$ \\
\hline Observations two/day & $\begin{array}{l}\text { Early afternoon } \\
\text { Evening }\end{array}$ & $\begin{array}{l}12.00 \text { to } 14.00 \text { hours } \\
20.00 \text { to } 22.00 \text { hours }\end{array}$ & $\frac{12}{2}(4 / 12 \mathrm{E})$ \\
\hline
\end{tabular}

E, early oestrus (intermittent refusal of male).

* Morning test but no mid-afternoon test.

pre-heat smears contained small cornified elements, which may have been either fragments of cornified epithelial cells, or intact cornified epithelial cells from a different part of the vaginal tract. They were smaller than nucleated epithelial cells, and have been provisionally termed 'transitional cells'. Most significantly, they appeared and disappeared earlier than, and independently of, the larger cornified epithelial cells. In twenty-nine out of thirty-three instances of oestrus, the appearance of these 'transitional cells' preceded the detection of receptivity. In two animals these cells were found after heat 
had begun and in the remainder (two) they could not be found at any time in conjunction with an observed heat. In four other instances, in which these elements were present and leucocytes were absent, the expected receptivity was not detected. Other cycle indicators, such as increase in nucleated or cornified epithelial cells, were relevant only in connection with leucocyte absence and/or appearance of the smaller cornified elements. In general, vaginal smears hinted only broadly at approaching heat, and change did not always follow expectation.

Elicitation of lordosis by fingering or some variation thereof was totally unreliable as an indicator of female receptivity. Females would often fail to respond to fingering just after displaying consistent lordosis in response to the male. Since mating was interrupted in order to avoid pregnancy or pseudopregnancy, the copulation plug method of detecting receptivity was useless.

\section{DISCUSSION}

The typical sequence of the cell types found in the vaginal smears was the same as that reported by Marston \& Chang (1965) for the Mongolian gerbil. This successive dominance of leucocytes, nucleated epithelial cells, and cornified cells had been reported in other murid rodents: rat (Long \& Evans, 1922); golden hamster (Kupperman, 1944); gerbils Tatera brantsi (A. Smith) and Tatera afra (Gray) (Measroch, 1954); and mouse (Bronson, Dagg \& Snell, 1966). The same succession was also found in the guinea-pig (Selle, 1922). The clear grouping of intervals between oestrous periods suggests that the cycle is 4 to 6 days long, and that the intervals of 14 to 18 days probably represent pseudopregnancies. They compare favourably with those found for pseudopregnancies in the rat (Wang, 1923), the mouse (Deanesly, 1930) and the golden hamster (Deanesly, 1938), and with that mentioned by Marston \& Chang (1965) for the gerbil. It is likely, on the basis of studies on the rat, both of pseudopregnancy (Ball, 1934) and of stimulation necessary for successful pregnancy (Wilson, Adler \& LeBoeuf, 1965), that the cause of these probable pseudopregnancies was not the few intromissions permitted in mating, but rather faulty technique in the lavage procedure, causing occasional cervical stimulation. There was no testing for deciduomata formation.

In studies involving gerbil mating behaviour, the best period for detection of behavioural oestrus on a 05.00 to 17.00 hours' light schedule would be 18.00 to 20.00 hours. Females receptive in the morning would be still in heat, and those beginning in the early or mid-afternoon would also be receptive. Marston \& Chang (1965) described a similar situation in their gerbils. In daily inspections at 09.00 hours and 17.00 hours, with lights from 07.00 to 19.00 hours, they observed $69 \%$ of the known matings at 17.00 hours, and the rest were deduced from broken spermatozoa found at 09.00 hours on the following day. A few matings were observed as early as 13.00 hours. Ovulation occurred by midnight in most females.

The data suggest that the period of receptivity in the gerbil begins slightly earlier in the light period than it does in most rodents (Bruce \& Hindle, 1934; Ball, 1937; Snell, Fekete, Hummel \& Law, 1940; Marston \& Chang, 1966), but 
light dependency of the cycle has not been checked by reversal of the light schedule.

\section{REFERENCES}

BaLl, J. (1934) Demonstration of a quantitative relation between stimulus and response in pseudopregnancy in the rat. Am. F. Physiol. 107, 698.

Ball, J. (1937) A test for measuring sexual excitability in the female rat. Comp. Psychol. Monogr. 14, 1.

Bronson, F. H., DAGg, C. P. \& Snell, G. D. (1966) Reproduction. In: Biology of the Laboratory Mouse, 2nd edn. Ed. E. L. Green. McGraw-Hill, New York.

Bruce, H. M. \& Hindle, E. (1934) The golden hamster, Cricetus (Mesocricetus) auratus Waterhouse. Notes on its breeding and growth. Proc. zool. Soc. Lond. (1934), 361.

DeanesLy, R. (1930) The corpora lutea of the mouse with special reference to fat accumulation during the oestrous cycle. Proc. R. Soc. B, 106, 578.

Deanesly, R. (1938) The reproductive cycle of the golden hamster. Proc. zool. Soc. Lond. 108A, 31.

Gordon, S. \& CEKLeniak, W. P. (1960) Hypercholesteremia and absence of atheroma in the gerbil. (Abstract). Fedn Proc. Fedn Am. Socs exp. Biol. 19, 231.

Kuzhn, R. E. \& Zucker, I. (1966) Mating behavior of Meriones unguiculatus. (Abstract). Am. Zoologist, 6, 535.

Kupperman, H. S. (1944) Sexual cycle and dimorphic pigmentation in the golden hamster (Cricetus auratus Waterhouse). Endocrinology, 35, 225.

Long, J. A. \& Evans, H. M. (1922) The oestrus cycle in the rat and its associated phenomena. Mem. Univ. Calif. 6.

Lourrr, C. M. (1927) Reproductive behavior of the guinea pig. I. The normal mating behavior. 7 . comp. Psychol. 7, 247.

Marston, J. H. \& Chang, M. C. (1965) The breeding, management, and reproductive physiology of the Mongolian gerbil (Meriones unguiculatus). Lab. Anim. Care, 15, 34.

Marston, J. H. \& Chang, M. C. (1966) The morphology and timing of fertilization and early cleavage in the Mongolian gerbil and deer mouse. F. Embryol. exp. Morph. 15, 169.

Measroch, V. (1954) Growth and reproduction in the females of two species of gerbil, Tatera brantsi (A. Smith) and Tatera afra (Gray). Proc. zool. Soc. Lond. 124, 631 .

ReED, C. A. \& REED, R. (1946) The copulatory behavior of the golden hamster. F. comp. Psychol. 39, 7.

SELLE, R. (1922) Changes in the vaginal epithelium of the guinea pig during the oestrous cycle. $A m . \mathcal{J}$. Anat. 30, 429.

SNell, G. D., FeKeTE, E., Hummel, K. P. \& LAW, L. W. (1940) The relation of mating, ovulation and the estrous smear in the house mouse to time of day. Anat. Rec. 76, 39.

Stone, C. P. (1922) The congenital sexual behavior of the young male albino rat. F. comp. Psychol. 2, 95.

Walters, G. C., PeArt, J. \& Rogers, J. V. (1963) The gerbil as a subject in behavioral research. Psychol. Rep. 12, 315.

WANG, G. H. (1923) The relation between spontaneous activity and oestrous cycle in the white rat. Comp. Psychol. Monogr. 2, 6.

Wilson, J. R., AdLer, N. \& LeBoeur, B. (1965) The effects of intromission frequency on successful pregnancy in the female rat. Proc. natn. Acad. Sci. U.S.A. 53, 1392.

Wimer, R. E. \& Fuller, J. L. (1966) Patterns of behavior. In: Biology of the Laboratory Mouse, 2nd edn. Ed. E. L. Green. McGraw-Hill, New York.

Winkelmann, J. R. \& Getz, L. L. (1962) Water balance in the Mongolian gerbil. J. Mammal. 43, 150.

Woodcock, W. H. (1955) Management and breeding of a new laboratory species, Meriones libycus. $\mathcal{F}$. Anim. Techns Ass. 6, 10. 